\section{‘Covington' Sweetpotato Plant Survival and Yield Response to Preplant Irrigation, Planting Depth, and Transplant Size}

\author{
William B. Thompson ${ }^{1}$, Jonathan R. Schultheis ${ }^{1,5}$, \\ Sushila Chaudhari ${ }^{2,4}$, David W. Monks ${ }^{1}$, Katherine M. Jennings ${ }^{1}$, \\ and Garry L. Grabow ${ }^{3}$
}

\begin{abstract}
AdDitional INDEX wORDS. Ipomoea batatas, storage root number
SUMMARY. A research gap exists on the effects of irrigation, transplant (nonrooted stem cuttings) size, and planting depth on sweetpotato (Ipomoea batatas) plant survival and storage root yield. Field studies were conducted in 2012 and 2013 to determine the effects of preplant irrigation, planting depth, and transplant size on sweetpotato plant stand, storage root number, and yield. Treatments included four transplant sizes $(3.7,6.3,8.5$, and 10.7 inches), two planting depths ( 2 and 6 inches), and preplant irrigation or nonirrigation. Overall, plant stand, storage root number, and yield were greater when transplants of size $\geq 6.3$ inches were planted 6 inches deep as compared with transplants planted 2 inches deep. The use of preplant irrigation had an overall positive impact on plant stand, storage root number, and yield under dry soil conditions. When moisture was readily available, neither plant stand nor storage root numbers were affected by the application of irrigation as observed in 2013. However, sweetpotato yields were greater during both years when preplant irrigation was used. Irrigation during the root initiation phase of plant establishment or extended periods of no rainfall would be beneficial for improving plant stands and yields.
\end{abstract}

S weetpotato is an important crop in the United States and was worth over \$716 million in gross farm value in 2015 [U.S. Department of Agriculture (USDA), 2016a] with North Carolina, California, Mississippi,

We acknowledge and thank Jonathan Monks, summer interns, graduate students, and all the staff at the Horticulture Crops Research Station, Clinton, NC, including Rodney Mozinga and Wesley Hairr for their assistance in planting and managing the research plots. We gratefully acknowledge Jones Farm, Bailey, $\mathrm{NC}$, for the in-kind support of supplying plants for the 2012 study. In addition, we thank Joy Smith for her assistance with the statistical data analysis. Finally, we would like to acknowledge the U.S. Department of Agriculture which administers the Specialty Crop Research Initiative Grant Program, and the North Carolina Sweetpotato Commission, Inc. for their financial support of this project.

Mention of a trademark, proprietary product, or vendor does not constitute a guarantee or warranty of the product by North Carolina State University and does not imply its approval to the exclusion of other products or vendors that also may be suitable.

${ }^{1}$ Department of Horticultural Science, North Carolina State University, Campus Box 7609, 2721 Founders Drive, Raleigh, NC 27695

${ }^{2}$ Department of Crop and Soil Sciences, North Carolina State University, Campus Box 7620, Raleigh, NC 27695

${ }^{3}$ Department of Biological and Agricultural Engineering, North Carolina State University, Campus Box 7625, Raleigh, NC 27695

${ }^{4}$ Postdoctoral Research Scholar.

${ }^{5}$ Corresponding author. E-mail: jonathan_schultheis@ ncsu.edu.

doi: 10.21273/HORTTECH03815-17 and Louisiana farmers planting over $89 \%$ of the production area (USDA, 2016b). North Carolina ranks number one in sweetpotato production in the United States with 87,000 acres planted ( $\$ 332$ million in gross farm value) in 2015, which accounts for more than half of the total acreage planted nationwide (USDA, 2016b). Sweetpotato transplant size and planting depth in production fields are important considerations because sweetpotato is vegetatively propagated by using nonrooted stem cuttings (also called transplants or slips) for commercial production. The size of sweetpotato transplants can vary considerably in sweetpotato propagation beds (A. Thornton, personal communication). When transplanted into production fields, transplant sizes can affect the yield and quality of sweetpotato storage roots. Most growers use 7- to 14-inch-long transplants (considered optimal size transplants) to plant production fields (Barkley et al., 2017; Smith et al., 2009). The sweetpotato cultivar Covington is unlike most other commercial cultivars as it has a growth habit in which the top canopy leaves are mostly at the same height, but the location of the apical meristem can vary from being close to the top of the leaf canopy to a few inches below. Because the apical meristem location can vary with respect to the top of the canopy, transplant sizes for this variety often vary when cut on the propagation bed (Barkley et al., 2017). 'Covington' is grown on $88 \%$ of the sweetpotato acreage in North Carolina (North Carolina Crop Improvement Association, 2014).

Transplants are cut from plant beds by hand using a knife or by using mechanical plant cutters and then boxed by hand for planting in production fields (Smith et al., 2009). Thus, 'Covington' transplants often vary in plant size, which can lead to planting difficulties in the field. Extreme variation in plant size can lead to skips as laborers have challenges in handling and placing transplants into the fingers of a mechanical transplanter (Fig. 1). Variation in transplant size makes achieving a uniform planting depth for sweetpotato transplants difficult because planting depth is contingent on position of the transplant within the fingers of the mechanical transplanter. Laborers follow the mechanical transplanter to replant transplants by hand because laborers on the mechanical transplanter periodically fail to place good quality plants in the mechanical transplanter fingers. The planting depth can also affect transplant survival and overall yields because of the number of nodes located beneath the soil surface (Meyers et al., 2017). Sweetpotato transplants should be set deep, with

\begin{tabular}{llll}
\hline $\begin{array}{l}\text { Units } \\
\text { To convert U.S. to SI, } \\
\text { multiply by }\end{array}$ & U.S. unit & SI unit & $\begin{array}{l}\text { To convert SI to U.S., } \\
\text { multiply by }\end{array}$ \\
\hline 0.4047 & acre(s) & $\mathrm{ha}$ & 2.4711 \\
102.7902 & acre-inch(es) & $\mathrm{m}^{3}$ & 0.0097 \\
0.3048 & $\mathrm{ft}$ & $\mathrm{m}$ & 3.2808 \\
2.54 & inch(es) & $\mathrm{cm}$ & 0.3937 \\
25.4 & inch(es) & $\mathrm{mm}$ & 0.0394 \\
0.4536 & lb & $\mathrm{kg}$ & 2.2046 \\
1.1209 & lb/acre & $\mathrm{kg} \cdot \mathrm{ha}^{-1}$ & 0.8922
\end{tabular}




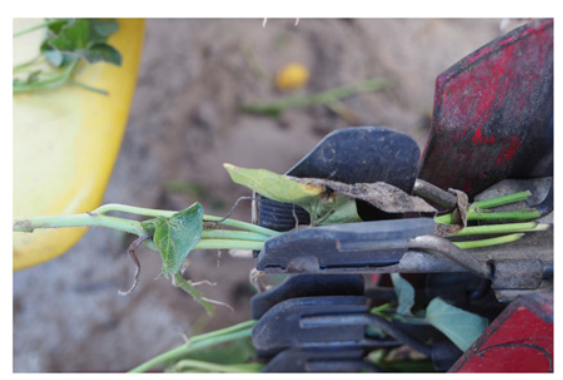

Fig. 1. Fingers of a commercial transplanter holding a sweetpotato transplant.

a portion of the plant above the soil surface, but with at least three nodes below the soil surface (Granberry et al., 1986). Other reports have shown that sweetpotato transplants are typically planted at a depth of 7.6-10.2 cm (34 inches) and several nodes are placed underground to maximize potential root set (Boudreaux et al., 2005).

Environmental conditions such as precipitation and initial soil moisture have also been shown to be key components to transplant survival and root set in sweetpotato (Gajanayake et al., 2013; Meyers et al., 2017). Soil moisture stress during plant establishment can limit the initial growth and development of sweetpotato roots and eventually affect storage root yield (Indira and Kabeerathumma, 1988; Pardales and Esquibel, 1997). Sweetpotato are often grown on nonirrigated lands and have been considered drought-tolerant (Constantin et al., 1974), although the response to moisture stress varies with variety (Villareal et al., 1979). According to Nair (2000), storage root yield decreases if drought conditions exist in the initial 10-30 d after planting (DAP), which is the time period of storage root initiation. Edmond and Ammerman (1971) also reported reduced storage root yields if drought occurred within the first 6 weeks after planting.

Sweetpotato growers have some knowledge about the transplant size that should be used to maximize plant stands, but documentation as to the interaction of preplant irrigation, transplant size, and planting depth and their resulting effect on plant survival and storage root quality and yield is limited. Thus, studies were conducted to determine the effect of transplant size, planting depth, and preplant irrigation on 'Covington' sweetpotato transplant survivability and storage root yield and quality.

\section{Materials and methods}

Field studies were conducted in 2012 and 2013 at the Horticulture Crops Research Station, Clinton, NC (lat. $35.0243^{\circ} \mathrm{N}$, long. $78.2827^{\circ} \mathrm{W}$ ). The soil was a Norfolk fine sandy loam (fine-loamy, kaolinitic, thermic Typic Kandiudults) with humic matter less than $0.7 \%$ and $\mathrm{pH}$ 6.0. A complete set of transplant size and planting depth treatments were arranged in a randomized complete block design with four replications in nonirrigated and preplant irrigated plots. To ensure optimal soil moisture levels, irrigation of 0.5 acre-inch was applied to the preplant irrigated portion of the field $1 \mathrm{~d}$ before planting using a linear move system. Nonirrigation plots were placed on opposite sides within the same field with a border area of 10 rows $(35 \mathrm{ft})$ between the plantings to ensure no water overspray from the irrigation event. Transplant size ranged from 3.0 to $4.5,5.5$ to 7,8 to 9 , and 9.5 to 12 inches (hereafter 3.7-, 6.3-, 8.5-, and 10.7-inch transplants, respectively). Transplants were measured from the base of the cut transplant to the tip of the growing point, and the number of nodes per transplant was counted. The average number of nodes per transplant was $4.9,7.0,8.2$, and 9.8 for 3.7-, 6.3-, 8.5-, and 10.7-inch transplants, respectively. The planting depths of transplants were 2 and 6 inches beneath the soil surface, with 2 inches representing a shallow commercial planting depth and 6 inches being the average planting depth of a mechanical transplanter used by growers (A. Thornton, personal communication). Transplants were established in the plots with a 0.25 inch-diameter wooden dowel that was used to make holes that were sufficient in diameter to plant the transplants. A stake was attached either 2 or 6 inches from the base of the dowel rod and served as the base for the dowel rod. When the dowel rod is inserted into the soil, the stake would flush at the top of the soil, therefore ensuring that the soil depths were exactly 2 or 6 inches. In 2012 and 2013 , the soil was dry, making it difficult to form holes in the nonirrigated portion of the field without soil in the holes falling in before getting the transplants planted. To alleviate this problem, a mechanical transplanter with no transplants was run over the top of the rows with the transplant water running continuously. The transplant water and packing wheels firmed the soil enough so that when planting holes were formed with dowels, soil did not fall back into the hole. This soil firmness allowed for the prescribed planting of the transplants at 2 or 6 inches, depending on the treatment. The planting dates were 20-21 June 2012 and 17 June 2013. Each plot was one 15-ftlong (12-inch-tall bed) row on 3.5-ft centers with 5 -ft borders (front, back) between plots.

All studies were culturally managed in accordance with North Carolina recommendations for weed, insect, and disease management (Kemble et al., 2014). Fertilizers for each study were based on soil test recommendations provided by the North Carolina Department of Agriculture and Consumer Services, Raleigh.

Once plants had been established, plant stands were recorded at 2-3 weeks after planting. Sweetpotato storage roots were harvested on 11-12 Oct. (114 DAP) and 18 Oct. (123 DAP) in 2012 and 2013, respectively. Storage roots from each plot were dug with a shovel by hand, collectively graded, and then counted and weighed. Storage roots were graded in accordance with the U.S. standards into no. 1 (diameter of 1.75-3.5 inches and length of 3-9 inches), canner (diameter $1-1.75$ inches), jumbo (diameter $>3.5$ inches), and culls (malformed, distorted, or diseased) (USDA, 2005). Marketable number and yield were calculated as the sum of no. 1, jumbo, and canner grades.

All data were checked for homogeneity of variance and normality. All the data were subjected to analysis of variance using the PROC GLIMMIX procedure of SAS (version 9.4; SAS Institute, Cary, NC) to test for treatment effects and interactions. Means were separated using Fisher's protected least significant differences at $P \leq 0.05$, when appropriate.

\section{Results and discussion}

The results are presented separately for 2012 and 2013 because of the significant interactions of year by treatments and variations in environment each year. A key reason for variations between environments among 
years could be the higher amounts of rainfall in 2013 compared with 2012 (Fig. 2). Three-way interactions between irrigation $\times$ planting depth $\times$ transplant size were not observed for the percent plant stand, all grades of storage root numbers and yields during 2012 and 2013 (P>0.05). Therefore, only significant two-way interactions and main effects are discussed further to explain the results.

2012. Plant stand, no. 1, jumbo, canner, cull, marketable, and total storage root numbers were influenced by a significant interaction of planting depth $\times$ transplant size $(P<0.05)$. The smallest size transplants ( 3.7 inches) had a plant stand (76\%) equal to or higher than all other transplant sizes when planted at the 2 -inch depth (Table 1), but had the lowest plant stand $(19 \%)$ at the 6 -inch planting depth. Transplants of 8.5 and 10.7 inches length had lower plant stands when planted 2 inches deep (61\% and $59 \%$, respectively) than transplants planted at 6 inches deep $(93 \%$ and $84 \%$, respectively). Plant stands were greatest among the largest size (8.5 and 10.7 inches) transplants when planted at 6 inches deep. Transplants of all sizes planted 2 inches deep produced the same number of no. 1 , jumbo, canner, cull, marketable, and

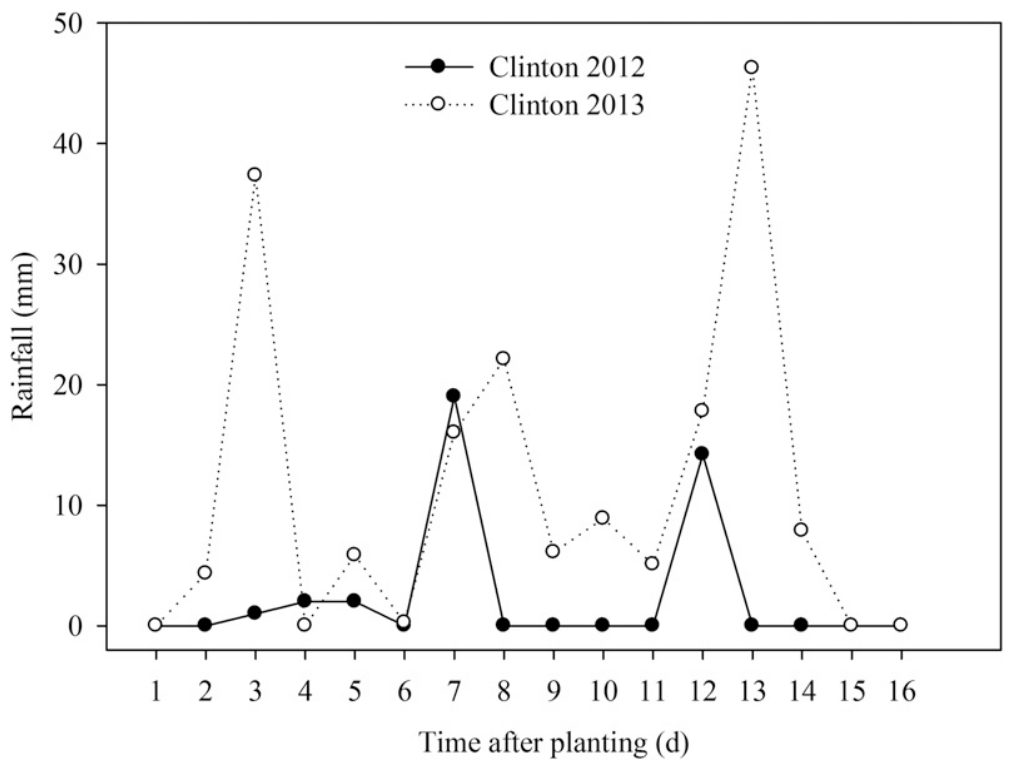

Fig. 2. Rainfall from 0 to $16 \mathrm{~d}$ after sweetpotato planting at Clinton in 2012 and 2013. Rainfall data were collected from regional weather stations and provided by the State Climate Office in North Carolina; $1 \mathrm{~mm}=0.0394$ inch. total storage roots regardless of the transplant size. However, the effect of transplant size was significant at the 6-inch planting depth, and at this planting depth, 3.7-inch transplants had the lowest no. 1, jumbo, canner, cull, marketable, and total storage roots than all other transplant sizes. Overall, higher numbers of no. 1, jumbo, canner, cull, marketable, and total storage roots were produced when transplants $\geq 6.3$ inches were planted 6 inches deep compared with 2 inches deep.

Significant interactions were observed for irrigation $\times$ transplant size for plant stand and no. 1, marketable, and total storage root numbers $(P<$ $0.05)$. The 3.7-inch transplants had the lowest plant stand for both preplant irrigation (57\%) and nonirrigation $(38 \%)$ treatments as compared with all other transplant sizes (Table $2)$. The 3.7-inch transplants always had the lowest numbers of no. 1, marketable, and total storage roots compared with all other transplant sizes under the nonirrigation treatment. The same trends occurred under preplant irrigation conditions, but were not statistically significant. Plant stands and numbers of no. 1, canner, cull, marketable, and total storage roots were greater when preplant irrigation $(75 \%$ and $20.8,16.5$, $2.1,42.5$, and $44.2 \times 1000$ roots/ acre, respectively) was applied compared with nonirrigation $(60 \%$ and $7.8,6.2,0.7,17.5$, and $17.9 \times 1000$ roots/acre, respectively).

The two-way interaction of planting depth $\times$ transplant size was

Table 1. Sweetpotato storage root numbers and plant stand in response to planting depth and transplant size at Clinton, NC, in 2012.

\begin{tabular}{|c|c|c|c|c|c|c|c|c|}
\hline \multicolumn{2}{|c|}{ Dependent variables } & No. 1 & Jumbo & Canner & Cull & Marketable ${ }^{y}$ & Total & \multirow[b]{2}{*}{ Stand $(\%)$} \\
\hline Planting depth (inches) ${ }^{\mathrm{z}}$ & Transplant size (inches) & \multicolumn{6}{|c|}{ Roots $(1,000 / \text { acre })^{\mathrm{z}}$} & \\
\hline 2 & 3.7 & $15.6^{x}$ & 3.9 & 10.4 & 1.2 & 32.5 & 33.5 & $76 \mathrm{ab}$ \\
\hline & 8.5 & 15.2 & 5.5 & 11.9 & 1.9 & 33.3 & 35.2 & $61 \mathrm{bc}$ \\
\hline & 10.7 & 13.3 & 4.6 & 7.9 & 0.4 & 27.8 & 28.3 & $59 \mathrm{c}$ \\
\hline Significance $^{\mathrm{w}}$ & & NS & NS & NS & NS & NS & NS & * \\
\hline & 8.5 & $28.2 \mathrm{a}$ & $6.4 \mathrm{a}$ & $28.6 \mathrm{a}$ & $2.3 \mathrm{a}$ & $65.2 \mathrm{a}$ & $67.5 \mathrm{a}$ & $93 \mathrm{a}$ \\
\hline & 10.7 & $27.2 \mathrm{a}$ & $6.1 \mathrm{a}$ & $23.7 \mathrm{a}$ & $2.1 \mathrm{a}$ & $60.8 \mathrm{a}$ & $62.9 \mathrm{a}$ & $84 \mathrm{ab}$ \\
\hline Significance & & * & * & * & * & * & * & * \\
\hline
\end{tabular}

${ }^{\mathrm{z}} 1$ inch $=2.54 \mathrm{~cm}, 1,000$ roots $/$ acre $=2,471.0538$ roots $/$ ha.

${ }^{\mathrm{y}}$ Marketable number $=$ no. $1+$ canner + jumbo; total number $=$ marketable + cull; no. 1 roots $=1.75-3.5$ inches diameter and $3-9$ inches long; canner roots $=1-1.75$ inches diameter; jumbo roots $\geq 3.5$ inches diameter; and cull roots $=$ malformed or distorted

${ }^{\mathrm{x}}$ Means followed by a different letter within a column are significantly different according to Fisher's protected LSD $(\alpha=0.05)$.

${ }^{\mathrm{NS},}{ }^{*}$ Nonsignificant and significant at $\alpha=0.05$, respectively. 
significant for all storage root yield grades $(P<0.05)$. When planted at the 6-inch depth, yields of each grade were lower from 3.7-inch transplants than other size transplants, but this difference was not observed at the 2inch planting depth (Table 3 ). At the 2 -inch planting depth, cull yield was lower for 10.7-inch transplants than 6.3- and 8.5-inch transplants. The effect of irrigation was also significant. Higher yields of no. 1, canner, cull, marketable, and total storage roots occurred when preplant irrigation was applied [281, 54, 27, 484, and 511 bushels /acre, respectively $(1$ bushel $=$ $50 \mathrm{lb})$ ] compared with nonirrigation (172, 39, 11, 417, and 429 bushels/ acre, respectively) (data not shown).
The exception was jumbo grade yield as nonirrigation (207 bushels/acre) yielded more than preplant irrigation (149 bushels/acre) (data not shown).

2013. The interaction of planting depth $\times$ transplant size was significant for plant stand, marketable, and total storage root numbers $(P<$ $0.05)$. Similar to the results in 2012 , transplants $\geq 6.3$ inches planted at 6 inches deep had higher plant stands and produced more marketable and total storage roots than 3.7-inch transplants (Table 4). However, this difference was not significant at the shallow planting depth of 2 inches.

The interaction of irrigation $x$ transplant size was significant for plant stand and canner, marketable, and total storage root numbers $(P<$ $0.05)$. The effect of transplant size was significant for the nonirrigation treatments where 3.7-inch transplants produced the fewest number of canner, marketable, and total storage roots, and the lowest plant stand compared with all other transplant sizes (Table 5). In contrast, when irrigated, no differences in percent plant stand and storage root numbers were observed for the various transplant sizes.

Transplant size had a significant effect on plant stand and no. 1 , canner, marketable, and total storage root numbers, whereas preplant irrigation significantly affected no. 1 , jumbo, and canner storage root numbers $(P<0.05)$.

Table 2. Sweetpotato storage root numbers and plant stand in response to irrigation and transplant size at Clinton, NC, in 2012.

\begin{tabular}{|c|c|c|c|c|c|c|c|c|}
\hline \multicolumn{2}{|c|}{ Dependent variables } & No. 1 & Jumbo & Canner & Cull & Marketable ${ }^{y}$ & Total & \multirow[b]{2}{*}{ Stand $(\%)$} \\
\hline Irrigation & Transplant size (inches) $^{\mathrm{z}}$ & \multicolumn{6}{|c|}{ Roots $(1,000 / \text { acre })^{\mathrm{z}}$} & \\
\hline \multirow[t]{4}{*}{ Preplant irrigated } & 3.7 & $11.4^{x}$ & $0.6 \mathrm{~b}$ & 9.5 & $1.1 \mathrm{c}$ & 24.0 & 24.8 & $57 \mathrm{c}$ \\
\hline & 8.5 & 22.9 & $5.3 \mathrm{a}$ & 19.9 & $3.2 \mathrm{a}$ & 49.3 & 52.5 & $82 \mathrm{ab}$ \\
\hline & 10.7 & 23.8 & $4.2 \mathrm{a}$ & 16.0 & $1.6 \mathrm{bc}$ & 45.2 & 46.4 & $75 \mathrm{~b}$ \\
\hline & Significance $^{w}$ & NS & * & NS & * & NS & NS & * \\
\hline & 8.5 & $18.7 \mathrm{a}$ & $6.6 \mathrm{a}$ & $17.1 \mathrm{a}$ & 0.9 & $44.1 \mathrm{a}$ & $45.3 \mathrm{a}$ & $72 \mathrm{a}$ \\
\hline & 10.7 & $15.2 \mathrm{a}$ & $6.7 \mathrm{a}$ & $11.8 \mathrm{a}$ & 0.9 & $37.5 \mathrm{a}$ & $38.4 \mathrm{a}$ & $68 \mathrm{a}$ \\
\hline & Significance & * & * & * & NS & * & * & * \\
\hline Preplant irrigated ${ }^{\mathrm{v}}$ & & $20.8 \mathrm{a}$ & 2.5 & $16.5 \mathrm{a}$ & $2.1 \mathrm{a}$ & $42.5 \mathrm{a}$ & $44.2 \mathrm{a}$ & $76 a$ \\
\hline Nonirrigated & & $7.8 \mathrm{~b}$ & 2.4 & $6.2 \mathrm{~b}$ & $0.7 \mathrm{~b}$ & $17.5 \mathrm{~b}$ & $17.9 \mathrm{~b}$ & $60 \mathrm{~b}$ \\
\hline
\end{tabular}

${ }^{\mathrm{z}} 1$ inch $=2.54 \mathrm{~cm}, 1,000$ roots $/$ acre $=2,471.0538$ roots $/$ ha.

${ }^{\mathrm{y}}$ Marketable number $=$ no. $1+$ canner + jumbo; total number $=$ marketable + cull; no. 1 roots $=1.75-3.5$ inches diameter and $3-9$ inches long; canner roots $=1-1.75$ inches diameter; jumbo roots $\geq 3.5$ inches diameter; and cull roots $=$ malformed or distorted

${ }^{\mathrm{x}}$ Means followed by a different letter within a column are significantly different according to Fisher's protected LSD ( $\left.\alpha=0.05\right)$.

${ }^{w_{N S}, ~ * N o n s i g n i f i c a n t ~ a n d ~ s i g n i f i c a n t ~ a t ~} \alpha=0.05$, respectively.

vereplant irrigation treatment received 0.5 acre-inch $\left(51.40 \mathrm{~m}^{3}\right)$ irrigation $1 \mathrm{~d}$ before planting using a linear move system.

Table 3. Sweetpotato storage root yield in response to planting depth and transplant size at Clinton, NC, in 2012.

\begin{tabular}{|c|c|c|c|c|c|c|c|}
\hline \multicolumn{2}{|c|}{ Dependent variables } & No. 1 & Jumbo & Canner & Cull & Marketable $\mathrm{y}$ & Total \\
\hline Planting depth (inches) ${ }^{\mathrm{z}}$ & Transplant size (inches) & \multicolumn{6}{|c|}{ Yield (bushels/acre) ${ }^{\mathrm{z}}$} \\
\hline \multirow[t]{3}{*}{2} & 3.7 & $199^{x}$ & 163 & 43 & $19 \mathrm{ab}$ & 405 & 424 \\
\hline & 8.5 & 190 & 188 & 34 & $25 \mathrm{a}$ & 412 & 437 \\
\hline & 10.7 & 177 & 197 & 26 & $5 \mathrm{~b}$ & 400 & 405 \\
\hline \multirow{3}{*}{$\begin{array}{l}\text { Significance }{ }^{w} \\
6\end{array}$} & & NS & NS & NS & * & NS & NS \\
\hline & 8.5 & $340 \mathrm{a}$ & $233 \mathrm{a}$ & $83 \mathrm{a}$ & $35 \mathrm{a}$ & $656 a$ & $692 \mathrm{a}$ \\
\hline & 10.7 & $330 \mathrm{a}$ & $199 a$ & $74 \mathrm{ab}$ & $26 \mathrm{ab}$ & $603 a$ & $629 \mathrm{ab}$ \\
\hline Significance & & * & * & * & * & * & * \\
\hline
\end{tabular}

${ }^{\mathrm{z}} \mathrm{l}$ inch $=2.54 \mathrm{~cm}, 150-\mathrm{lb}(22.68 \mathrm{~kg}) \mathrm{bushel} / \mathrm{acre}=56.0426 \mathrm{~kg} \cdot \mathrm{ha}^{-1}$

${ }^{\mathrm{y}}$ Marketable number $=$ no. $1+$ canner + jumbo; total number $=$ marketable + cull; no. 1 roots $=1.75-3.5$ inches diameter and $3-9$ inches long; canner roots $=1-1.75$ inches diameter; jumbo roots $\geq 3.5$ inches diameter; and cull roots $=$ malformed or distorted

${ }^{\mathrm{x}}$ Means followed by a different letter within a column are significantly different according to Fisher's protected LSD $(\alpha=0.05)$.

${ }^{\mathrm{N}} \mathrm{N},{ }^{*}$ Nonsignificant and significant at $\alpha=0.05$, respectively. 
Table 4. Sweetpotato storage root number and plant stand in response to planting depth and transplant size at Clinton, NC, in 2013.

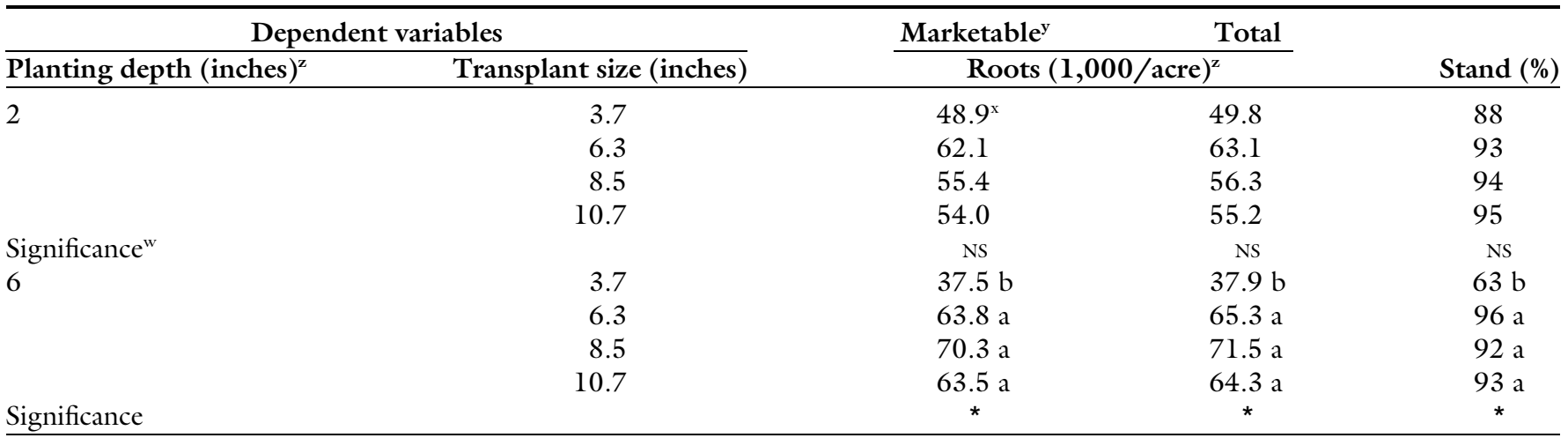

${ }^{\mathrm{z}} 1$ inch $=2.54 \mathrm{~cm}, 1,000$ roots $/$ acre $=2,471.0538$ roots $/$ ha.

${ }^{\mathrm{y}}$ Marketable number $=$ no. $1+$ canner + jumbo; total number $=$ marketable + cull; no. 1 roots $=1.75-3.5$ inches diameter and $3-9$ inches long; canner roots $=1-1.75$ inches diameter; jumbo roots $\geq 3.5$ inches diameter; and cull roots $=$ malformed or distorted.

${ }^{\mathrm{x}}$ Means followed by a different letter within a column are significantly different according to Fisher's protected LSD $(\alpha=0.05)$.

${ }^{\mathrm{w}} \mathrm{NS},{ }^{*}$ Nonsignificant and significant at $\alpha=0.05$, respectively.

Table 5. Sweetpotato storage root number and plant stand in response to irrigation and transplant size at Clinton, NC, in 2013.

\begin{tabular}{|c|c|c|c|c|c|}
\hline \multicolumn{2}{|c|}{ Dependent variables } & Canner & Marketable & Total & \multirow[b]{2}{*}{ Stand (\%) } \\
\hline Irrigation & Transplant size (inches) $^{\mathrm{z}}$ & \multicolumn{3}{|c|}{ Roots $(1,000 / \text { acre })^{\mathrm{z}}$} & \\
\hline \multirow[t]{4}{*}{ Preplant irrigated ${ }^{x}$} & 3.7 & $10.6^{\mathrm{w}}$ & 52.2 & 52.9 & 87 \\
\hline & 8.5 & 9.4 & 58.1 & 58.6 & 96 \\
\hline & 10.7 & 9.5 & 58.5 & 59.3 & 93 \\
\hline & Significance $^{\mathrm{v}}$ & NS & NS & NS & NS \\
\hline & 8.5 & $24.7 \mathrm{a}$ & $67.2 \mathrm{a}$ & $68.8 \mathrm{a}$ & $90 \mathrm{a}$ \\
\hline & 10.7 & $17.0 \mathrm{a}$ & $58.7 \mathrm{a}$ & $59.8 \mathrm{a}$ & $94 \mathrm{a}$ \\
\hline & Significance & * & * & * & * \\
\hline
\end{tabular}

${ }^{\mathrm{z}} 1$ inch $=2.54 \mathrm{~cm}, 1,000$ roots $/$ acre $=2,471.0538$ roots $/$ ha.

${ }^{y}$ Marketable number $=$ no. $1+$ canner + jumbo; total number $=$ marketable + cull; no. 1 roots $=1.75-3.5$ inches diameter and $3-9$ inches long; canner roots $=1-1.75$ inches

diameter; jumbo roots $\geq 3.5$ inches diameter; and cull roots $=$ malformed or distorted.

${ }^{x}$ Preplant irrigation treatment received 0.5 acre-inch $\left(51.40 \mathrm{~m}^{3}\right)$ irrigation $1 \mathrm{~d}$ before planting using a linear move system.

${ }^{\mathrm{w}}$ Means followed by a different letter within a column are significantly different according to Fisher's protected LSD ( $\left.\alpha=0.05\right)$.

${ }^{\mathrm{N}} \mathrm{NS},{ }^{*}$ Nonsignificant and significant at $\alpha=0.05$, respectively.

Transplants $\geq 6.3$-inch size produced higher plant stand and numbers of no. 1 , canner, marketable, and total storage roots, whereas 3.7-inch transplants consistently produced the lowest plant stand and number of storage roots for all grades (Table 6). The effect of irrigation was not as great in 2013 (Table 6) as it was in 2012 (Table 2). Higher numbers of no. 1 and jumbo storage roots were produced from the preplant irrigation treatment than using the nonirrigation treatment.

Planting depth and transplant size only influenced canner yield where 3.7-inch transplants yielded lower than 6.3- and 8.7-inch transplants (Table 7). The effect of irrigation was significant for all storage root grades except for cull yield, with preplant irrigation treatment having higher yield of no. 1, jumbo, marketable, and total storage roots than the nonirrigation treatment.

These results showed that planting depth, irrigation, and transplant size have a significant impact on sweetpotato plant stand and storage root yield. The interaction between transplant size and planting depth was an important factor for sweetpotato transplant survival and storage root production during both the years except sweetpotato yield in 2013 . This interaction demonstrated that transplants planted at the deeper planting depth (6 inches) showed a beneficial response for plant stand and storage root set among transplant sizes $\geq 6.3$ inches. As a consequence, transplants that ranged from 6.3 to
10.7 inches consistently produced the highest plant stand, storage root numbers, and yields when transplants were planted 6 inches deep. Our results are in agreement with recommendations by Kemble et al. (2014) where transplants that ranged from 8 to 12 inches produced higher plant stand and yields. The larger transplant size likely produced more storage roots because of the increased number of nodes planted beneath the soil surface. More nodes beneath the soil increased the yield potential, as each node is a source of adventitious root development and potential storage root formation (Boudreaux et al., 2005). The 3.7-inch transplants planted 6 inches deep had consistently lower sweetpotato plant stand and storage root numbers and yields, 
Table 6. Sweetpotato storage root number and plant stand in response to irrigation and transplant size at Clinton, NC, in 2013.

\begin{tabular}{|c|c|c|c|c|c|c|c|}
\hline \multirow[b]{2}{*}{ Dependent variables } & No. 1 & Jumbo & Canner & Cull & Marketable $^{\mathrm{y}}$ & Total & \\
\hline & \multicolumn{6}{|c|}{ Roots $(1,000 / \text { acre })^{\mathrm{z}}$} & Stand $(\%)$ \\
\hline \multicolumn{8}{|c|}{ Transplant size (inches) ${ }^{\mathrm{z}}$} \\
\hline 6.3 & $30.7 \mathrm{a}$ & 10.5 & $18.4 \mathrm{a}$ & 1.2 & $63.0 \mathrm{a}$ & $64.2 \mathrm{a}$ & $95 \mathrm{a}$ \\
\hline 8.5 & $31.9 \mathrm{a}$ & 11.7 & $15.2 \mathrm{ab}$ & 1.1 & $62.4 \mathrm{a}$ & $63.5 \mathrm{a}$ & $93 \mathrm{a}$ \\
\hline 10.7 & $28.9 \mathrm{a}$ & 13.0 & $12.7 \mathrm{bc}$ & 1.0 & $58.6 \mathrm{a}$ & 59.6 a & $94 \mathrm{a}$ \\
\hline Preplant irrigated ${ }^{v}$ & $31.7 \mathrm{a}$ & $13.2 \mathrm{a}$ & $10.8 \mathrm{~b}$ & 0.7 & 57.6 & 58.3 & 92 \\
\hline Nonirrigated & $25.2 \mathrm{~b}$ & $7.3 \mathrm{~b}$ & $17.8 \mathrm{a}$ & 1.4 & 54.5 & 55.6 & 86 \\
\hline Significance & * & * & * & NS & NS & NS & NS \\
\hline
\end{tabular}

${ }^{\mathrm{z}} 1$ inch $=2.54 \mathrm{~cm}, 1,000$ roots $/$ acre $=2,471.0538$ roots $/$ ha.

${ }^{\mathrm{y}}$ Marketable number $=$ no. $1+$ canner + jumbo; total number $=$ marketable + cull; no. 1 roots $=1.75-3.5$ inches diameter and $3-9$ inches long; canner roots $=1-1.75$ inches diameter; jumbo roots $\geq 3.5$ inches diameter; and cull roots $=$ malformed or distorted.

${ }^{\mathrm{x}}$ Means followed by a different letter within a column are significantly different according to Fisher's protected LSD $(\alpha=0.05)$.

${ }^{\mathrm{N}} \mathrm{NS},{ }^{*}$ Nonsignificant and significant at $\alpha=0.05$, respectively.

${ }^{\mathrm{v}}$ Preplant irrigation treatment received 0.5 acre-inch $\left(51.40 \mathrm{~m}^{3}\right)$ irrigation $\mathrm{l} \mathrm{d}$ before planting using a linear move system.

Table 7. Sweetpotato storage root yield in response to planting depth, irrigation, and transplant size at Clinton, NC, in 2013.

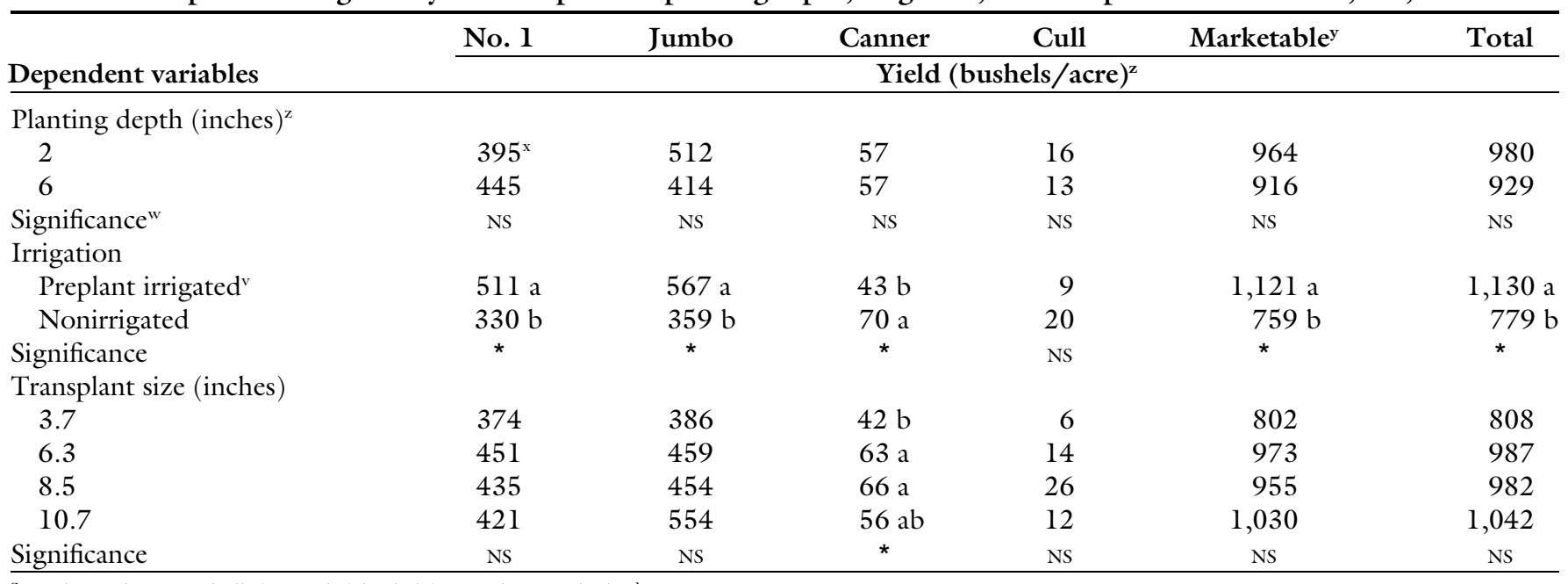

${ }^{\mathrm{z}} 1$ inch $=2.54 \mathrm{~cm}, 150 \mathrm{lb}(22.68 \mathrm{~kg})$ bushel $/$ acre $=56.0426 \mathrm{~kg} \cdot \mathrm{ha}^{-1}$.

${ }^{\mathrm{y}}$ Marketable number $=$ no. $1+$ canner + jumbo; total number $=$ marketable + cull; no. 1 roots $=1.75-3.5$ inches diameter and $3-9$ inches long; canner roots $=1-1.75$ inches diameter; jumbo roots $\geq 3.5$ inches diameter; and cull roots = malformed or distorted.

${ }^{\mathrm{x}}$ Means followed by a different letter within a column are significantly different according to Fisher's protected LSD $(\alpha=0.05)$.

${ }^{\text {w }}$ N, * Nonsignificant and significant at $\alpha=0.05$, respectively.

veplant irrigation treatment received 0.5 acre-inch $\left(51.40 \mathrm{~m}^{3}\right)$ irrigation $1 \mathrm{~d}$ before planting using a linear move system.

when compared with planting at the 2 inch planting depth. This result is likely due to environmental and physiological stresses as the 3.7-inch transplants were completely buried under soil at the planting depth of 6 inches. The use of transplants that were too small and planted too deep resulted in stunted transplant growth/slowed development, or ultimately killed the plant. Similarly, transplants $\geq 8.5$ inches planted 2 inches deep had lower sweetpotato plant stand, storage root numbers, and yield when compared with same size transplants planted at 6 inches deep. The exception was plant stand during 2013 , which ranged from $92 \%$ to $96 \%$ regardless of planting depth. Larger size transplants planted at 2 inches depth likely had fewer nodes covered with soil, which resulted in reduced plant survival and storage root production. Deeper planting most likely provided transplants with a more stable environment. Soil temperature and volumetric water content nearer the soil surface can be highly variable, whereas those at greater depths are more consistent (Meyers, 2013). It was reported in studies of other vegetatively propagated crops, such as cassava, that longer plants result in better stands and higher yields than shorter plants (Ekandem, 1962; Rodriguez and Sanchez de Bustamante, 1963).
The growing seasons for our studies were variable and are representative of the challenges that every sweetpotato grower faces. Environmental conditions such as precipitation and initial soil moisture have been shown to be the key components for transplant survival and storage root set in sweetpotato (Gajanayake et al., 2013; Indira and Kabeerathumma, 1988; Pardales and Esquibel, 1997). The irrigation $\times$ transplant size interaction was an important factor for sweetpotato transplant survival and storage root numbers during both the years. The importance of selecting transplants $\geq 6.3$ inches for 
sweetpotato plant stand and storage root number was mainly observed with nonirrigation or when soil conditions were drier at planting (Tables 3 and 6). However, sweetpotato yields were influenced by the use of irrigation in both the years, with higher yield observed with preplant irrigation than without. The impact of preplant irrigation on plant stand and cull, marketable, and total storage root numbers was significant in 2012 , but not in 2013. In 2012, the beneficial response of preplant irrigation was likely because of the environmental conditions being less favorable at the time of planting as measurable rainfall did not occur until 5 DAP (Fig. 2). However, the 2013 study demonstrated that preplant irrigation did not play as much of a role in plant stand and marketable and total storage root numbers as rainfall was constant through most of the plant establishment and root initiation period, $\approx 13 \mathrm{DAP}$ (Villordon et al., 2009). These results confirm previous research conducted by Lana and Peterson (1956) and Bowers et al. (1956) who found that sweetpotato yields were increased by irrigation up to $67 \%$. An important difference between their studies and ours was that in their studies, irrigation was applied throughout the entire growing season, whereas the irrigation treatment in our study was applied only during plant establishment.

These results showed that longer transplants $(\geq 6.3$ inches $)$ planted 6 inches deep have improved plant stand and produced greater numbers and yield of sweetpotato storage roots. The use of irrigation can be beneficial for overall yields and improving plant stands, especially if it is very hot and dry during plant establishment. The use of irrigation at planting when soil moisture is optimal may not be necessary. However, if soils are dry during the root initiation phase of plant establishment or if there are long periods of no rainfall during the season, preplant irrigation would be beneficial to overall yield.

\section{Literature cited}

Barkley, S.L., S. Chaudhari, J.R. Schultheis, K.M. Jennings, S.G. Bullen, and D.W. Monks. 2017. Optimizing sweetpotato seed root density and size for transplant production. HortTechnology 27:7-15.

Boudreaux, J.E., J.M. Cannon, and A. Villordon. 2005. Commercial vegetable production recommendations. Louisiana State Univ. Agr. Ctr. Bul. 2433.

Bowers, J.L., R.H. Benedict, and J. McFerren. 1956. Irrigation of sweet potatoes, snap beans, and cucumber in Arkansas. Arkansa Agr. Expt. Sta. Bul. 578.

Constantin, R.J., T.P. Hernandez, and L.G. Jones. 1974. Effect of irrigation and nitrogen fertilization on quality of sweetpotatoes. J. Amer. Soc. Hort. Sci. 99:308-310.

Edmond, J.B. and G.R. Ammerman. 1971. Sweetpotatoes: Production, processing, and marketing. AVI Publ., Westport, CT.

Ekandem, M.J. 1962. Cassava in Nigeria. Part 1. Fed. Dept. Agr. Res. Memo 42:3-4.

Gajanayake, B., K.R. Reddy, M.W. Shankle, and R.A. Arancibia. 2013. Early-season soil moisture deficit reduces sweetpotato storage root initiation and development. HortScience 48:1457-1462.

Granberry, D.M., P. Colditz, and W.J. McLaurin. 1986. Sweet potato. Georgia Expt. Bul. 677.

Indira, P. and S. Kabeerathumma. 1988. Physiological response of sweetpotato under water stress. 1 . Effect of water stress during the different phases of tuberization. J. Root Crops 14:37-40.

Kemble, J.M., L.M. Quesada-Ocampo, K.L. Ivors, K.M. Jennings, and J.F. Walgenbach (eds.). 2014. Southeastern US 2014 vegetable crop handbook. Vance Publ., Lincolnshire, IL.

Lana, E.P. and L.E. Peterson. 1956. The effect of fertilizer-irrigation combinations on sweet potatoes in Buckner coarse sand. Proc. Amer. Soc. Hort. Sci. 68:400-405.

Meyers, S.L. 2013. Transplant planting tips. Mississippi Sweet Potato Crop Rpt. 2.

Meyers, S.L., M.W. Shankle, J. Main, B. Gajanayake, and K.R. Reddy. 2017.
Sweetpotato storage root initiation. Mississippi State Univ. Expt. Publ. 2809.

Nair, G.M. 2000. Cultural and manurial requirements of sweetpotato production technology of tuber crops, p. 44-72. In: C.R. Mohankumar, G.M. Nair, C. George, S. Ravindran, and V. Ravi (eds.). Production technology of tuber crops. Ctr. Tuber Crops Res. Inst., Kerala, India.

North Carolina Crop Improvement Association. 2014. Seed list 2013-14. 22 Apr. 2015. <http://www.nccrop.com/ varieties.php $/ 8 /$ Sweetpotato $>$.

Pardales, J.R., Jr., and C.B. Esquibel. 1997. Root development in sweetpotato stem cuttings as influenced by pre-planting, planting, and post-planting practices. Ann. Trop. Res. 19:56-65.

Rodriguez, N.F. and C.A. Sanchez de Bustamante. 1963. Importance of type of cutting for the production of cassava in Misiones. Revista Investigacion Agricola Buenos Aires 17:289-302.

Smith, T.P., S. Stoddard, M. Shankle, and J.R. Schultheis. 2009. The sweetpotato, p. 287-323. In: G. Loebenstein and G. Thottappilly (eds.). Sweetpotato production in the United States. Springer, Dordrecht, The Netherlands.

U.S. Department of Agriculture. 2005. United States standards for grades of sweetpotatoes. U.S. Dept. Agr., Washington, DC.

U.S. Department of Agriculture. 2016a. Crop values 2015 summary. U.S. Dept. Agr., Washington, DC.

U.S. Department of Agriculture. 2016b. Crop production 2015 summary. U.S. Dept. Agr., Washington, DC.

Villareal, R.L., S.L. Lin, and S.H. Lai. 1979. Variations in yielding ability of sweetpotato under drought stress and minimum input conditions. HortScience 14:31-32.

Villordon, A.Q., D.R. La Bonte, N. Firon, Y. Kfir, E. Pressman, and A. Schwartz. 2009. Characterization of adventitious root development in sweetpotato. HortScience 44:651-655. 